\title{
Characterising populations living close to intensive farming and composting facilities in England
}

\author{
Philippa Douglas $(\bowtie)^{1,2}$, Daniela Fecht ${ }^{3}$, Deborah Jarvis ${ }^{1}$ \\ 1 National Heart and Lung Institute, MRC Centre for Environment and Health, Imperial College London, London, SW3 6LZ, UK \\ 2 Centre for Radiation, Chemical and Environmental Hazards, Public Health England, Harwell Campus, Didcot, Oxfordshire, OX11 0RQ, UK \\ 3 UK Small Area Health Statistics Unit, MRC Centre for Environment and Health, School of Public Health, Imperial College London, \\ London, W2 1PG, UK
}

\section{H I G H L I G H T S}

- Bioaerosol emitted from farming and composting facilities may pose health risks.

- We describe population characteristics around these sites and infer public concern.

- Sites were mapped and overlaid with population, demographic and school data.

- Approximately $16 \%$ of the population and $15 \%$ of schools are located near these sites.

- More community health studies need to be conducted around these sites.

\section{A R T I C L E I N F O}

Article history:

Received 18 May 2020

Revised 28 September 2020

Accepted 11 October 2020

Available online 4 November 2020

\section{Keywords:}

Composting

Intensive farming

Bioaerosol

Population characteristics

Public health

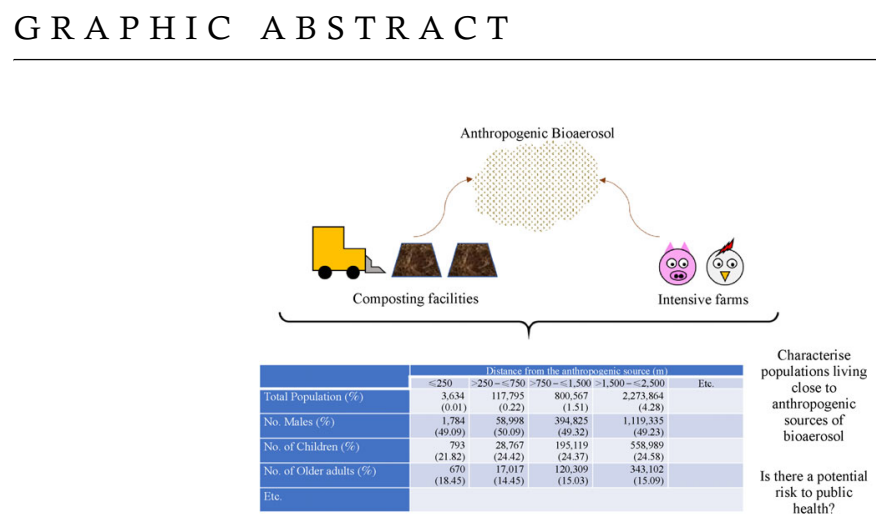

\section{A B S T R A C T}

Bioaerosol exposure has been linked to adverse respiratory conditions. Intensive farming and composting facilities are important anthropogenic sources of bioaerosols. We aimed to characterise populations living close to intensive farming and composting facilities. We also infer whether the public are becoming more concerned about anthropogenic bioaerosol emissions, using reports of air pollution related incidents attributed to facilities. We mapped the location of 1,257 intensive farming and 310 composting facilities in England in relation to the resident population and its characteristics (sex and age), area characteristics (deprivation proxy and rural/urban classification) and school locations stratified by pre-defined distance bands from these bioaerosol sources. We also calculated the average number of air pollution related incidents per year per facility. We found that more than $16 \%$ of the population and $15 \%$ of schools are located within $4,828 \mathrm{~m}$ of an intensive farming facility or 4,000 $\mathrm{m}$ of a composting facility; few people $(0.01 \%)$ live very close to these sites and tend to be older people. Close to composting facilities, populations are more likely to be urban and more deprived. The number of incidents were attributed to a small proportion of facilities; population characteristics around these facilities were similar. Results indicate that populations living near composting facilities (particularly $>250$ to $\leqslant 4,000 \mathrm{~m}$ ) are mostly located in urban areas $(80 \%-88 \%$ of the population), which supports the need for more community health studies to be conducted. Results could also be used to inform risk management strategies at facilities with higher numbers of incidents.

C The Author(s) 2020. This article is published with open access at link.springer.com and journal.hep. com.cn

\section{Introduction}

$\triangle$ Corresponding author

E-mail: philippa.douglas@phe.gov.uk

Special Issue-Bioaerosol, Environment and Health (Responsible Editors: Can Wang, Jungho Hwang, Jingkun Jiang \& Maosheng Yao)
Food production and waste management is increasing to meet the demands of an expanding population (estimated to rise by $4.5 \%$ in the UK, from mid-2018 to mid-2028 (ONS, 2020a)). The number of intensive farms in England has increased by $77 \%$ from 709 farms in 2010 to 1,258 
farms in 2017 to meet the increasing demand in food (Environment Agency, 2018a) (Fig. 1). Composting facilities provide a sustainable way of recycling biodegradable waste. The number of composting facilities in England has increased by 134\% from 140 in 2010 to 327 in 2017 (Environment Agency, 2018b; Robertson et al., 2019) (Fig. 1).

Intensive farming facilities and industrial scale composting facilities represent important anthropogenic sources of bioaerosol. Bioaerosols are airborne microorganisms consisting of a complex mixture of fungi, bacteria, pollen, particulate and by-products of cells (Pepper and Dowd, 2009; Douwes et al., 2003; Pearson et al., 2015; Walser et al., 2015). Bioaerosols are ubiquitous in the natural environment but are emitted in elevated quantities from intensive farming and composting facilities. Due to their small size (typically $<3 \mu \mathrm{m}$ in diameter), bioaerosols have the potential to travel over large geographic distances (Tamer Vestlund et al., 2014; Fröhlich-Nowoisky et al., 2016; Feeney et al., 2018). Once aerosolised they are subjected to prevailing air current, convection, diffusion and gravitational settling (Brooks and Gerba, 2014). Exposure to bioaerosol poses important risks to human health.

As bioaerosols are small, they are inhalable and can travel deeply into the lungs, and may trigger allergenic, immunological or inflammatory responses. Bioaerosol exposure may cause exacerbations of, for example, allergic and non-allergic asthma, rhinitis, hypersensitivity pneumonitis, allergic alveolitis, allergic bronchopulmonary Aspergillosis, chronic bronchitis, chronic obstructive pulmonary disease (COPD), organic dust toxic syndrome, and toxic pneumonitis (Lacey and Dutkiewicz, 1994; Swan et al., 2003; Sykes et al., 2007; Wery, 2014; Pearson et al., 2015). Bioaerosols were highlighted as a substance that needs to be considered as a pollutant with potentially harmful effects on human health in the 2017 Chief Medical Officer for England's annual report on health impacts of pollution (Chief Medical Officer, 2018). Exposure to bioaerosols may represent a particular health risk to persons already living with allergies, respiratory diseases and those who are immunocompromised (Walser et al., 2015). Worldwide, approximately $30 \%$ of adults and $40 \%$ of children suffer from respiratory allergies, including allergic rhinitis and asthma (Pawankar et al., 2013; Allergy UK, 2020); asthma affects 5.4 million people in the UK (Allergy UK, 2020) with allergy being the cause of asthma in around $80 \%$ of cases (Pawankar et al., 2013; Allergy UK, 2020), and younger asthmatics having an even higher incidence of allergies (Allergy UK, 2020). However, at present, there are no quantitative dose-response estimates to derive health-related exposure limits for bioaerosol emissions from intensive farming or composting facilities (Pearson et al., 2015; Walser et al., 2015).

Recent systematic reviews of the literature (Pearson et al., 2015; Douglas et al., 2018; Robertson et al., 2019) highlighted that studies on health effects due to bioaerosol exposure have largely been conducted in occupational settings; few studies explored wider community health effects. In England, the extent of the population living in proximity to anthropogenic bioaerosol sources is, therefore, unknown, although it is widely thought that intensive farming and composting facilities are mostly located in rural areas away from residential homes and schools. The aim of our study was to identify the population living close to intensive farming and composting facilities and describe their socio-demographic characteristics. We also, use reports of air pollution-related incidents attributed to intensive farming and composting facilities collected by the Environment Agency (EA) in England between 2011 and 2017 to calculate the average number of air pollution related incidents per year per facility, and describe the

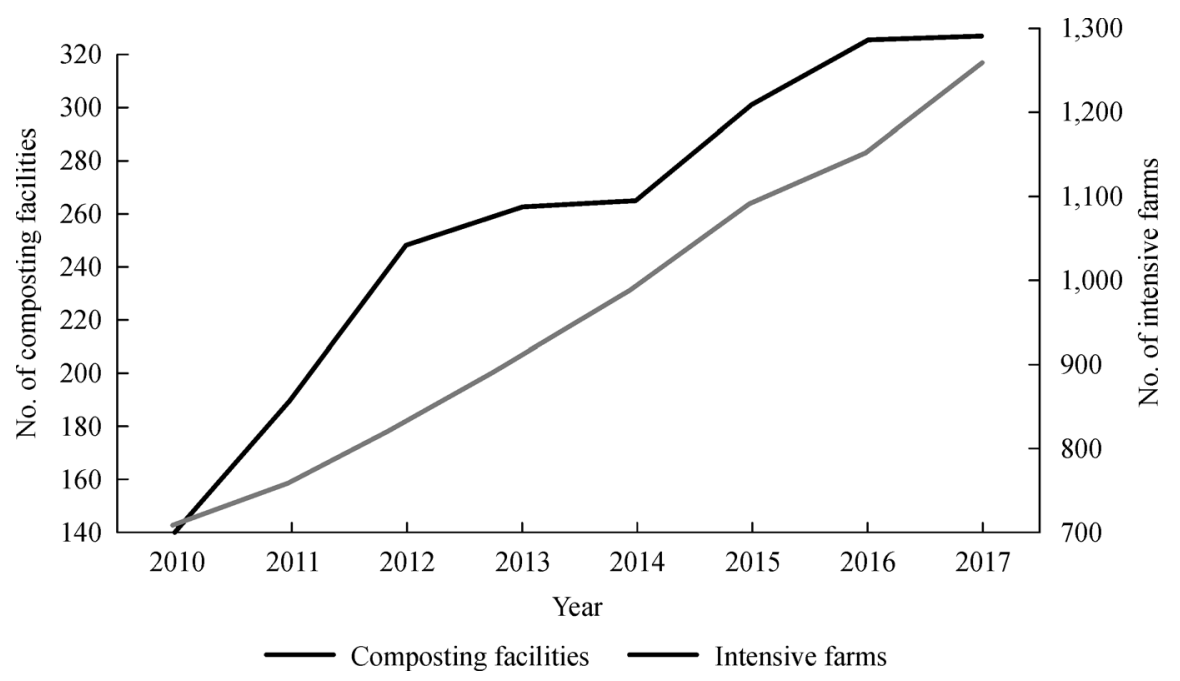

Fig. 1 The number of permitted intensive farming and composting facilities in England 2010-2017. Contains Environment Agency information (C) Environment Agency. 
socio-demographic characteristics around facilities with reported incidents.

\section{Materials and methods}

\subsection{Intensive farming and composting facility locations}

We included all intensive farming and composting facilities in England with a permit to operate at the end of 2017 , data were provided by the EA. Intensive farming facilities are regulated under the Industrial Emission Directive (IED), which defines intensives farming as installations with $>40,000$ places for poultry, or $>2,000$ places for production pigs (over $30 \mathrm{~kg}$ ), or $>750$ places for sows (2010/75/EU) (The European Parliament and the Council of the European Union, 2010). If classed as intensive farming under the IED, a permit from the EA is required. Similarly, composting facilities also require a permit from the EA to operate, if they store or treat $>80$ tonnes of compost at any one time ( $>60$ tonnes if the waste is brought in from another location or if the resultant compost is used elsewhere) (Environment Agency, 2014). Both datasets included a unique facility identifier (permit number), facility name, address, permit issue date, type of facility (for intensive farming the principle use is listed, e.g., an intensive farming facility could have pigs and poultry, but is registered under the primary operation), and a national grid reference. National grid references were used to geocode the intensive farming and composting facilities; national grid references are checked by the EA when the permit is given, and usually refer to the facility entrance (EA, Environment and Business Department, personal communication, 15th June 2018).

\subsection{Population characteristics}

We used population data from the most recent census (2011), available from the Office for National Statistics (ONS) at Census Output Area (COA) (average population of 300 people). This is the highest spatial resolution at which population estimates are available by sex and age categories (age is provided in five year age bands $(0-4,5-9$ etc. up to >85)) (ONS, 2020b). We calculated the number of children (classed as being aged $\leqslant 19$ years), and number of older adults (classed as being aged $\geqslant 65$ years) per COA.

\subsection{Area-level characteristics}

We used Carstairs 2011, a deprivation score available at COA level, as a proxy for area-level socioeconomic status. The Carstairs index consists of four domains which are calculated using census data from ONS: 1) male unemployment (proportion of economically active males aged $\geqslant 16$ years), 2) lack of car ownership (the proportion of households without a car), 3) overcrowding (the proportion of household with a density of $\geqslant 1$ person per room), 4) low social class (proportion of persons living in households with an economically active head of household in a low social class) (Carstairs and Morris, 1989). We categorised scores into quintiles for analysis. We did not consider using Index of Multiple Deprivation (IMD) data as this is produced at lower layer super output area (LSOA) (average population of 1,500 people), and the geographical area covered by each LSOA is too large for the purposes of this study.

We categorised COAs as rural or urban using ONS 2011 rural-urban classification data where COAs are categorised as urban if the population weighted centre is within an area with a resident population above 10,000 people (includes 'major conurbations', 'minor conurbations', 'city \& town'); all other COAs were categorised as rural (includes 'town \& fringe', 'villages', and 'hamlets \& isolated dwellings') (ONS, 2020c).

\subsection{School locations}

We obtained information on school locations in England (last updated in July 2017) from The Department for Education (GOV.UK, 2017), which contains information for 24,302 schools. The data contains the school address, type of school (nursery, primary, secondary etc.), and the age range of the students attending the school. We reclassified schools broadly into primary or secondary schools based on the school type: Secondary includes 'Secondary', 'Middle deemed secondary' and ' 16 plus' school types $(13 \%, n=3,257)$; Primary includes all other school types including 'Nursey', 'Primary', 'Middle deemed primary', 'All through' and 'Not applicable' $(87 \%, n=21,045)$. We geocoded schools based on the postcode centroid of their address; 144 schools $(<1 \%)$ could not be geocoded and we removed these from the analysis.

\subsection{Data analysis}

We mapped population and area-level characteristics at population weighted COA centroid and schools data at postcode centroids in relation to distance to the nearest (i) intensive farming facility and (ii) composting facility. The population-weighted centroid for each COA was calculated by adjusting the geometric COA centroid using postcode headcount information as weights (Equation 1), to reflect the population distribution within a given $\mathrm{COA}$ as follows:

$$
\begin{gathered}
X_{C O A P O P W C}=\frac{\Sigma_{C O A=1} X_{P C} * P O P_{P C}}{P C_{n}}, \\
Y_{C O A \text { POPWC }}=\frac{\Sigma_{C O A=1} Y_{P C} * P O P_{P C}}{P C_{n}},
\end{gathered}
$$


where: $X_{C O A} P O P W C$ and $Y_{C O A}$ POPWC are the $x, y$ coordinates of the population weighted COA centroid; $X_{P C}$ and $Y_{P C}$ are the $x, y$ coordinates of postcode centroids within the $\mathrm{COA} ; P O P_{P C}$ is the population associated with each postcode centroid within the COA; and $P C_{n}$ is the number of postcodes in the COA.

The distance of each COA population weighted centroid and school postcode centroid to the nearest (i) intensive farming facility and (ii) composting facility was calculated using ArcMap (version 10.2). Patterns in population and area-level characteristics were analysed in relation to distance from composting facilities and intensive farms. We used distance bands of $(0,100],(100,500],(500,1000]$, (1000,4828] (3 miles), $>4828 \mathrm{~m}$ (the rest of England) for intensive farming facilities and distance bands of $(0,250]$, $(250,750],(750,1500],(1500,2500],(2500,4000]$ and $>4,000 \mathrm{~m}$ (the rest of England) for composting facilities, corresponding to different bioaerosol exposure proxies used in published literature (Table 1). Population and arealevel characteristics for each distance band were compared to the rest of England using a Chi-squared test. Statistical analyses were conducted using Stata (version 15.0).

\subsection{Air pollution-related incidents}

We obtained Common Incident Classification Scheme (CICS) data from the EA on the number of air pollutionrelated incidents, and notifications of these incidents, attributed to intensive farming and composting facilities, to calculate the average number of air pollution related incidents per year per facility, and describe the sociodemographic characteristics around facilities with reported incidents. Although air pollution-related incidents are not just limited to bioaerosols, this information may still be indicative of incidents related to or caused by bioaerosols. Detailed methods are provided in Appendix A, and CICS definitions are provided in Appendix B.

\section{Results}

At the end of 2017, there were 1,257 intensive farming and 310 composting facilities with a permit to operate in England. Of the 1,257 intensive farms, 1,046 were primarily poultry farms, 176 were primarily pig farms and 35 were primarily sow farms. Of the 310 permitted composting facilities, 158 were classed as open windrow (compost process is usually conducted entirely outdoors; bioaerosols emissions are uncontrolled and uncontained), 25 facilities were in-vessel (compost process is mostly conducted indoors, occasionally with an outdoor maturation element; bioaerosol emissions may be somewhat more controlled and contained), 24 were classed as both open windrow and 103 were not classified.

Intensive farming facilities mostly clustered in rural areas, with a large proportion located in the East (near the counties the counties of Norfolk, Suffolk, and Lincolnshire) and the West (in areas bordering Wales). Compost-

Table 1 Justification for distance bands used for descriptive statistics for both intensive farms and composting facilities

\begin{tabular}{ll}
\hline Distance $(\mathrm{m})$ & Justification \\
\hline Intensive farms & Cuntent
\end{tabular}

100

500

1,000

4,828

Composting sites

250

750

1,500

2,500

4,000
Current distance set by the EA whereby an intensive farm has to conduct a 'site specific bioaerosols risk assessment' if there are any 'sensitive receptors' (e.g. a dwelling or workplace) within $100 \mathrm{~m}$ of the intensive farm (GOV.UK, 2018)

Distance used in two cross-sectional epidemiological studies that used proxy measures for exposure (Radon et al., 2007; Smit et al., 2014).

Distance used two epidemiological studies (one case-control and one cross-sectional) that used proxy measures for exposure (Smit et al., 2014; Huijskens et al., 2016). Schinasi et al., (2011) measured and detected bioaerosol (endotoxin) at around this distance (the exact location of monitoring is not stated in this study, although it is implied that is was conducted 'within $1.5 \mathrm{~km}$ ' of the farming facility).

Distance used in a cross-sectional epidemiological study that used proxy measures for exposure (equates to approx. 3 miles) (Mirabelli et al., 2006)

Current distance set by the EA whereby a composting facility has to conduct a 'site specific bioaerosols risk assessment' if there are any 'sensitive receptors' (e.g. a dwelling or workplace) within $250 \mathrm{~m}$ of the composting facility (Environment Agency, 2018c)

Distance bioaerosols have been detected above background levels from composting facilities at this distance (Pankhurst et al., 2011; Williams et al., 2013), and was a distance band used in a small area ecological epidemiological study (Douglas et al., 2016)

Distance bioaerosols have been detected from composting facilities (Reinthaler et al., 1997; Williams et al., 2013), and was a distance band used in a small area ecological study (Douglas et al., 2016)

Control distance used in small area ecological study were it was assumed that there was no contribution above background levels (Douglas et al., 2016)

Full extent of the area included in a recent dispersion modelling study that estimated bioaerosol exposure from composting facilities (Williams et al., 2019) and subsequent epidemiological analysis (Roca-Barcelo et al., 2020). A larger area was used compared to (Douglas et al., 2016) to account for the influence of wind speed and direction. 
ing facilities were more evenly spread across the UK, their distribution broadly reflecting population density with higher concentrations near large towns and cities, around London and the conurbations in the North West of England.

3.1 Characteristics of population residing close to intensive farming facilities

Table 2 presents summary statistics of population characteristics for COAs close to intensive farming facilities by distance bands. Approximately a fifth of the population in England (over 9.4 million people, 18\%) live within 4,828 $\mathrm{m}$ of an intensive farming facility; only 1,242 people $(<0.01 \%)$ live within COAs whose population weighted centroid is within $100 \mathrm{~m}$ of an intensive farming facility. Twenty percent of schools in England $(n=4,815)$ are within $4,828 \mathrm{~m}$ of an intensive farm $(4,221$ primary schools and 594 secondary schools); 2 primary schools are located within $100 \mathrm{~m}$ of an intensive farming facility.

Overall, the population within $100 \mathrm{~m}$ of an intensive farming facility is significantly older, less deprived, and more likely to be rural compared to those living $>100 \mathrm{~m}$ of an intensive farming facility $(p<0.01)$. Within $4,828 \mathrm{~m}$ of an intensive farming facility, there is a higher proportion of older adults, those classed as least deprived (a very small proportion is classified as being the most deprived $(0.00$ $12.21 \%)$ ), and a lower proportion of people living in an urban area, compared to the rest of England.

Deprivation patterns, however, vary considerably when stratified by rural and urban areas (Fig. 2). There is a larger proportion of more deprived populations living within urban areas close to intensive farms compared to rural areas.

Rural areas consist of populations in less deprived (Carstairs quintile 1 and 2) areas in all distance bands,

Table 2 Characteristics of Census Output Areas (COAs) and their population by distance bands from intensive farming facilities

\begin{tabular}{|c|c|c|c|c|c|c|}
\hline \multirow[t]{2}{*}{ Parameters } & & \multicolumn{5}{|c|}{ Distance from the facility $(\mathrm{m})$} \\
\hline & & $\leqslant 100$ & $(100,500]$ & $(500,1000]$ & $(1000,4828]$ & $>4828^{\mathrm{a}}$ \\
\hline No. of COAs $(\%)^{b}$ & & $\begin{array}{c}5 \\
(<0.01)\end{array}$ & $\begin{array}{c}215 \\
(0.13)\end{array}$ & $\begin{array}{c}920 \\
(0.54)\end{array}$ & $\begin{array}{l}29,973 \\
(17.49)\end{array}$ & $\begin{array}{l}140,235 \\
(81.84)\end{array}$ \\
\hline Total Population $(\%)^{\mathrm{b}}$ & & $\begin{array}{c}1,242 \\
(<0.01)\end{array}$ & $\begin{array}{c}64,351 \\
(0.12)\end{array}$ & $\begin{array}{c}280,089 \\
(0.53)\end{array}$ & $\begin{array}{c}9,128,573 \\
(17.19)\end{array}$ & $\begin{array}{c}43,624,402 \\
(82.16)\end{array}$ \\
\hline No. Males $(\%)^{\mathrm{b}}$ & & $\begin{array}{c}607 \\
(48.87)\end{array}$ & $\begin{array}{l}32,266 \\
(50.14)\end{array}$ & $\begin{array}{c}137,846 \\
(49.22)\end{array}$ & $\begin{array}{c}4,481,040 \\
(49.09)\end{array}$ & $\begin{array}{c}21,476,765 \\
(49.23)\end{array}$ \\
\hline No. of Children $(\%)^{\mathrm{b}, \mathrm{c}}$ & & $\begin{array}{c}287 \\
(23.11)\end{array}$ & $\begin{array}{l}14,322 \\
(22.26)\end{array}$ & $\begin{array}{l}63,921 \\
(22.82)\end{array}$ & $\begin{array}{c}2,130,369 \\
(23.34)\end{array}$ & $\begin{array}{c}10,500,165 \\
(24.07)\end{array}$ \\
\hline No. of Older adults $(\%)^{\mathrm{b}, \mathrm{d}}$ & & $\begin{array}{c}286 \\
(23.03)\end{array}$ & $\begin{array}{l}12,988 \\
(20.18)\end{array}$ & $\begin{array}{l}56,294 \\
(20.10)\end{array}$ & $\begin{array}{c}1,707,134 \\
(18.70)\end{array}$ & $\begin{array}{c}6,952,847 \\
(15.94)\end{array}$ \\
\hline \multirow{5}{*}{$\begin{array}{l}\text { Population per Carstairs } \\
\text { deprivation quintile }(\%)^{\mathrm{b}} \text {, } \\
1=\text { least deprived }\end{array}$} & 1 & $\begin{array}{c}825 \\
(66.43)\end{array}$ & $\begin{array}{l}19,021 \\
(29.56)\end{array}$ & $\begin{array}{l}102,127 \\
(36.46)\end{array}$ & $\begin{array}{c}2,504,974 \\
(27.44)\end{array}$ & $\begin{array}{c}8,210,471 \\
(18.82)\end{array}$ \\
\hline & 2 & $\begin{array}{c}283 \\
(22.79)\end{array}$ & $\begin{array}{l}21,008 \\
(32.65)\end{array}$ & $\begin{array}{l}85,862 \\
(30.66)\end{array}$ & $\begin{array}{c}2,357,213 \\
(25.82)\end{array}$ & $\begin{array}{c}8,637,416 \\
(19.80)\end{array}$ \\
\hline & 3 & $\begin{array}{c}0 \\
(0.00)\end{array}$ & $\begin{array}{l}14,687 \\
(22.82)\end{array}$ & $\begin{array}{l}49,188 \\
(17.56)\end{array}$ & $\begin{array}{c}1,789,619 \\
(19.60)\end{array}$ & $\begin{array}{c}8,490,728 \\
(19.46)\end{array}$ \\
\hline & 4 & $\begin{array}{c}134 \\
(10.79)\end{array}$ & $\begin{array}{l}5,855 \\
(9.10)\end{array}$ & $\begin{array}{c}27,964 \\
(9.98)\end{array}$ & $\begin{array}{c}1,362,499 \\
(14.93)\end{array}$ & $\begin{array}{c}8,468,270 \\
(19.41)\end{array}$ \\
\hline & 5 & $\begin{array}{c}0 \\
(0.00)\end{array}$ & $\begin{array}{l}3,780 \\
(5.87)\end{array}$ & $\begin{array}{l}14,948 \\
(5.34)\end{array}$ & $\begin{array}{c}1,114,163 \\
(12.21)\end{array}$ & $\begin{array}{c}9,817,387 \\
(22.50)\end{array}$ \\
\hline Population in Urban areas $(\%)^{\mathrm{b}}$ & & $\begin{array}{c}0 \\
(0.00)\end{array}$ & $\begin{array}{l}22,723 \\
(35.31)\end{array}$ & $\begin{array}{c}104,559 \\
(37.33)\end{array}$ & $\begin{array}{c}5,976,977 \\
(65.48)\end{array}$ & $\begin{array}{c}37,630,978 \\
(86.26)\end{array}$ \\
\hline \multirow[t]{3}{*}{ No. of Schools $(\%)^{\mathrm{e}}$} & Total & $\begin{array}{c}2 \\
(0.01)\end{array}$ & $\begin{array}{c}34 \\
(0.14)\end{array}$ & $\begin{array}{c}154 \\
(0.64)\end{array}$ & $\begin{array}{c}4,625 \\
(19.14)\end{array}$ & $\begin{array}{l}19,343 \\
(80.07)\end{array}$ \\
\hline & Primary education ${ }^{\mathrm{f}}$ & $\begin{array}{c}2 \\
(100.00)\end{array}$ & $\begin{array}{c}31 \\
(91.18)\end{array}$ & $\begin{array}{c}138 \\
(89.61)\end{array}$ & $\begin{array}{c}4,050 \\
(87.57)\end{array}$ & $\begin{array}{l}16,695 \\
(86.31)\end{array}$ \\
\hline & Secondary education ${ }^{\mathrm{g}}$ & $\begin{array}{c}0 \\
(0.00)\end{array}$ & $\begin{array}{c}3 \\
(8.82)\end{array}$ & $\begin{array}{c}16 \\
(10.39)\end{array}$ & $\begin{array}{c}575 \\
(12.43)\end{array}$ & $\begin{array}{c}2,648 \\
(13.69)\end{array}$ \\
\hline
\end{tabular}

Notes: a. Comparison area; b. Based on data available at COA level, where the COA population weighted centroid falls within the stated distance bands; c. Number of children aged $\leqslant 19$ years, based on data available at COA level; d. Number of elderly adults aged $\geqslant 65$ years, based on data available at COA level; e. Based on data available at postcode level; $\mathrm{f}$. Number of schools classed as 'Primary', 'Middle deemed primary', 'Nursery', 'All through', 'Not applicable' or classification is missing (mean average lowest age of students $=4.19$, mean average highest age of students =11.48); g. Number of schools classed as 'Secondary', 'Middle deemed secondary', or '16 plus' (mean average lowest age of students $=11.06$, mean average highest age of students $=17.30$ ). 

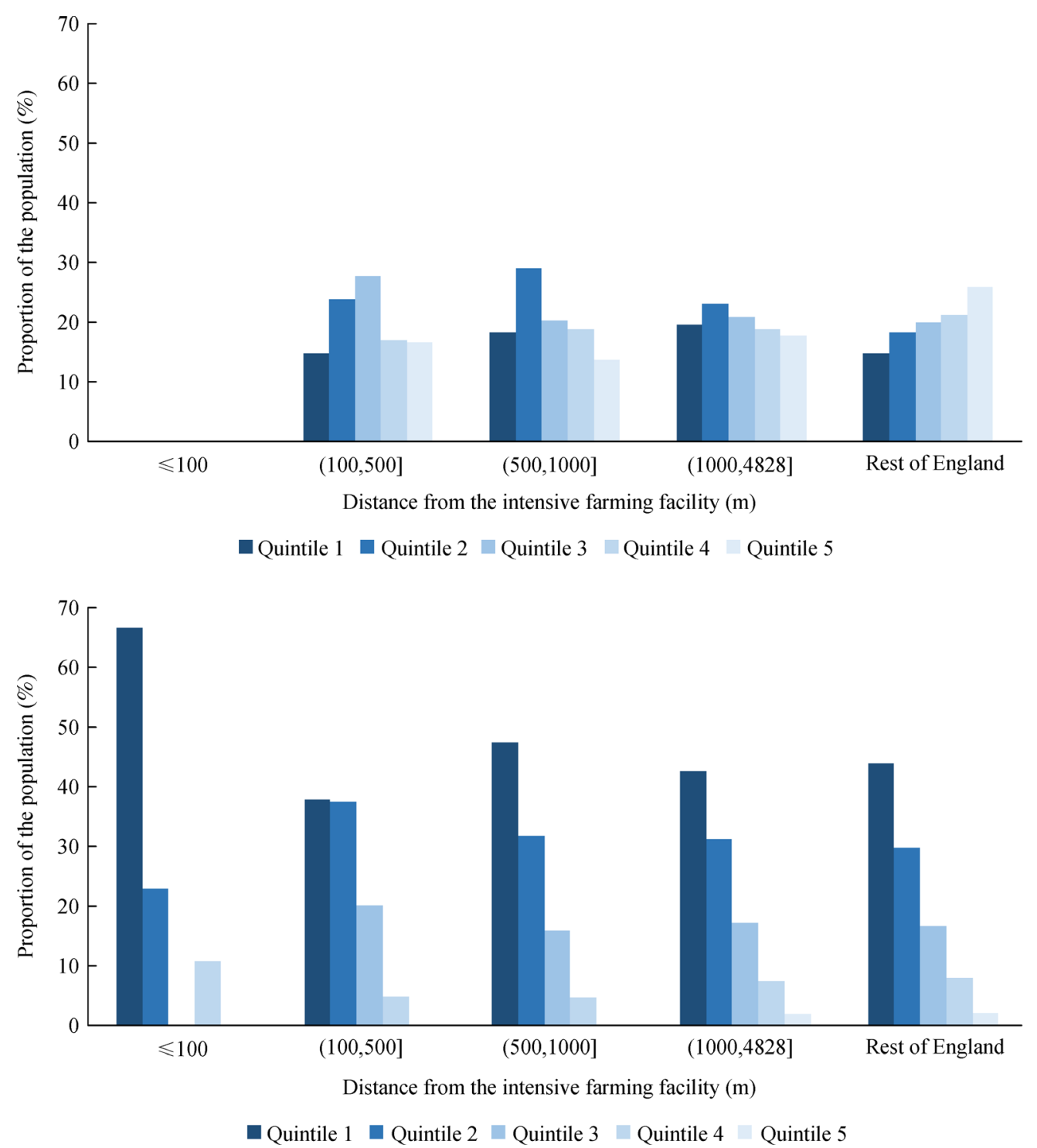

Fig. 2 Proportion of the population living within each Carstairs deprivation quintile by distance band from intensive farming facility, for urban areas (top) and rural areas (bottom). A deprivation quintile of 1 represents the least deprived areas.

although this is more marked within $100 \mathrm{~m}$ of an intensive farming facility. We explored this further by applying an adapted Carstairs index for use in rural settings (Rural Carstairs, RCar) (Fecht et al., 2017), which we applied to populations living in rural areas near intensive farms in a sensitivity analysis (see Appendix $\mathrm{C}$ for methods and results). When using RCar, the population living in each deprivation quintile changes markedly, with a much lower proportion of people being classified in the least deprived quintiles, and a higher proportion being classified in the more deprived quintiles. Overall, the population living within $4,828 \mathrm{~m}$ of an intensive farm, particularly those living within $100 \mathrm{~m}$, remain classified as being not very deprived, but a larger proportion of the population is more deprived than shown in Table 2 .
The number of incidents and notifications attributed to intensive farm facilities per year are presented in Appendix D.

\subsection{Population characteristics around composting facilities}

Table 3 presents summary statistics of population characteristics for COAs close to composting facilities by distance bands. Approximately a sixth of the population in England (over 8.5 million people, 16\%) live within 4,000 $\mathrm{m}$ of a composting facility; only 3,634 people $(0.01 \%)$ live within COAs whose population weighted centroid is within $100 \mathrm{~m}$ of a composting facility. Fifteen percent of schools in England $(n=3,707)$ are within $4,000 \mathrm{~m}$ of a composting facility $(3,205$ primary schools and 502 
Table 3 Characteristics of Census Output Areas (COAs) and their population by distance bands to composting facilities

\begin{tabular}{|c|c|c|c|c|c|c|c|}
\hline & \multicolumn{6}{|c|}{ Distance from the facility $(\mathrm{m})$} \\
\hline & & $\leqslant 250$ & $(250,750]$ & $(750,1500]$ & $(1500,2500]$ & $(2500,4000]$ & $>4000^{\mathrm{a}}$ \\
\hline \multicolumn{2}{|l|}{ No. of COAs $(\%)^{\mathrm{b}}$} & $\begin{array}{c}14 \\
(0.01)\end{array}$ & $\begin{array}{c}393 \\
(0.23)\end{array}$ & $\begin{array}{l}2,638 \\
(1.54)\end{array}$ & $\begin{array}{l}7,333 \\
(4.28)\end{array}$ & $\begin{array}{l}17,148 \\
(10.01)\end{array}$ & $\begin{array}{l}143,822 \\
(83.93)\end{array}$ \\
\hline \multicolumn{2}{|l|}{ Total Population $(\%)^{\mathrm{b}}$} & $\begin{array}{l}3,634 \\
(0.01)\end{array}$ & $\begin{array}{c}117,795 \\
(0.22)\end{array}$ & $\begin{array}{c}800,567 \\
(1.51)\end{array}$ & $\begin{array}{c}2,273,864 \\
\quad(4.28)\end{array}$ & $\begin{array}{l}5,397,106 \\
(10.16)\end{array}$ & $\begin{array}{c}44,505,691 \\
(83.82)\end{array}$ \\
\hline \multicolumn{2}{|l|}{ No. Males $(\%)^{\mathrm{b}}$} & $\begin{array}{c}1,784 \\
(49.09)\end{array}$ & $\begin{array}{l}58,998 \\
(50.09)\end{array}$ & $\begin{array}{c}394,825 \\
(49.32)\end{array}$ & $\begin{array}{c}1,119,335 \\
(49.23)\end{array}$ & $\begin{array}{c}2,665,270 \\
(49.38)\end{array}$ & $\begin{array}{c}21,888,312 \\
\quad(49.18)\end{array}$ \\
\hline \multicolumn{2}{|l|}{ No. of Children $(\%)^{\mathrm{b}, \mathrm{c}}$} & $\begin{array}{c}793 \\
(21.82)\end{array}$ & $\begin{array}{l}28,767 \\
(24.42)\end{array}$ & $\begin{array}{l}195,119 \\
(24.37)\end{array}$ & $\begin{array}{l}558,989 \\
(24.58)\end{array}$ & $\begin{array}{l}1,319,026 \\
(24.44)\end{array}$ & $\begin{array}{c}10,606,380 \\
(23.83)\end{array}$ \\
\hline \multicolumn{2}{|c|}{ No. of Older adults $(\%)^{\mathrm{b}, \mathrm{d}}$} & $\begin{array}{c}670 \\
(18.45)\end{array}$ & $\begin{array}{l}17,017 \\
(14.45)\end{array}$ & $\begin{array}{l}120,309 \\
(15.03)\end{array}$ & $\begin{array}{c}343,102 \\
(15.09)\end{array}$ & $\begin{array}{c}803,207 \\
(14.88)\end{array}$ & $\begin{array}{c}7,445,244 \\
(16.73)\end{array}$ \\
\hline \multicolumn{2}{|c|}{$\begin{array}{l}\text { Population per Carstairs1 } \\
\text { deprivation quintile }(\%)^{\mathrm{b}}\end{array}$} & $\begin{array}{l}1,075 \\
(29.58)\end{array}$ & $\begin{array}{l}18,579 \\
(15.77)\end{array}$ & $\begin{array}{c}126,054 \\
(15.75)\end{array}$ & $\begin{array}{l}363,433 \\
(15.98)\end{array}$ & $\begin{array}{l}847,395 \\
(15.70)\end{array}$ & $\begin{array}{l}9,480,882 \\
(21.30)\end{array}$ \\
\hline \multirow[t]{4}{*}{$1=$ least deprived } & 2 & $\begin{array}{c}621 \\
(17.09)\end{array}$ & $\begin{array}{l}22,547 \\
(19.14)\end{array}$ & $\begin{array}{c}133,273 \\
(16.65)\end{array}$ & $\begin{array}{l}396,851 \\
(17.45)\end{array}$ & $\begin{array}{c}946,459 \\
(17.54)\end{array}$ & $\begin{array}{l}9,602,031 \\
(21.57)\end{array}$ \\
\hline & 3 & $\begin{array}{c}496 \\
(13.65)\end{array}$ & $\begin{array}{l}24,225 \\
(20.57)\end{array}$ & $\begin{array}{l}150,469 \\
(18.79)\end{array}$ & $\begin{array}{l}408,199 \\
(17.95)\end{array}$ & $\begin{array}{c}979,953 \\
(18.16)\end{array}$ & $\begin{array}{c}8,780,880 \\
(19.73)\end{array}$ \\
\hline & 4 & $\begin{array}{c}539 \\
(14.83)\end{array}$ & $\begin{array}{l}19,606 \\
(16.64)\end{array}$ & $\begin{array}{l}161,655 \\
(20.19)\end{array}$ & $\begin{array}{c}451,892 \\
(19.88)\end{array}$ & $\begin{array}{c}1,057,539 \\
(19.59)\end{array}$ & $\begin{array}{c}8,173,491 \\
(18.37)\end{array}$ \\
\hline & 5 & $\begin{array}{c}903 \\
(24.85)\end{array}$ & $\begin{array}{l}32,838 \\
(27.88)\end{array}$ & $\begin{array}{l}229,116 \\
(28.62)\end{array}$ & $\begin{array}{r}653,489 \\
(28.74)\end{array}$ & $\begin{array}{l}1,565,760 \\
(29.01)\end{array}$ & $\begin{array}{c}8,468,172 \\
(19.03)\end{array}$ \\
\hline \multicolumn{2}{|c|}{ Population in Urban areas $(\%)^{\mathrm{b}}$} & $\begin{array}{c}1,884 \\
(51.84)\end{array}$ & $\begin{array}{l}95,321 \\
(80.92)\end{array}$ & $\begin{array}{c}672,577 \\
(84.01)\end{array}$ & $\begin{array}{c}1,938,788 \\
(85.26)\end{array}$ & $\begin{array}{c}4,773,548 \\
(88.45)\end{array}$ & $\begin{array}{c}36,253,119 \\
(81.46)\end{array}$ \\
\hline \multirow[t]{3}{*}{ No. of Schools $(\%)^{\mathrm{e}}$} & Total & $\begin{array}{c}1 \\
(<0.01)\end{array}$ & $\begin{array}{c}47 \\
(0.19)\end{array}$ & $\begin{array}{c}368 \\
(1.52)\end{array}$ & $\begin{array}{c}972 \\
(4.02)\end{array}$ & $\begin{array}{l}2,319 \\
(9.60)\end{array}$ & $\begin{array}{l}20,451 \\
(84.66)\end{array}$ \\
\hline & Primary educationf & $\begin{array}{c}1 \\
(100.00)\end{array}$ & $\begin{array}{c}41 \\
(87.23)\end{array}$ & $\begin{array}{c}329 \\
(89.40)\end{array}$ & $\begin{array}{c}843 \\
(89.40)\end{array}$ & $\begin{array}{c}1,991 \\
(86.73)\end{array}$ & $\begin{array}{l}17,711 \\
(86.60)\end{array}$ \\
\hline & $\begin{array}{l}\text { Secondary educa- } \\
\text { tiong }\end{array}$ & $\begin{array}{c}0 \\
(0.00)\end{array}$ & $\begin{array}{c}6 \\
(12.77)\end{array}$ & $\begin{array}{c}39 \\
(10.60)\end{array}$ & $\begin{array}{c}129 \\
(13.27)\end{array}$ & $\begin{array}{c}328 \\
(13.27)\end{array}$ & $\begin{array}{c}2,740 \\
(13.40)\end{array}$ \\
\hline
\end{tabular}

Notes: a. Comparison area - 'the rest of England'; b. Based on data available at COA level, where the COA population weighted centroid falls within the stated distance bands; c. Number of children aged $\leqslant 19$ years, based on data available at COA level; d. Number of older adults aged $\geqslant 65$ years, based on data available at COA level; e. Based on data available at postcode level; f. Number of schools classed as 'Primary', 'Middle deemed primary', 'Nursery', 'All through', 'Not applicable' or classification is missing (mean average lowest age of students $=4.19$, mean average highest age of students $=11.48$ ); $\mathrm{g}$. Number of schools classed as 'Secondary',

'Middle deemed secondary', or '16 plus' (mean average lowest age of students $=11.06$, mean average highest age of students $=17.30$ ).

secondary schools; one school (a primary school) is located within $250 \mathrm{~m}$ of a composting facility.

Overall, the population living within $250 \mathrm{~m}$ of a composting facility as a significantly lower proportion of children, a higher proportion of older adults, less deprived, and more likely to be rural $(p<0.03)$ compared to those living $>250 \mathrm{~m}$ of a composting facility. Within $4,000 \mathrm{~m}$ there was a higher proportion of people living classified as most deprived compared to the rest of England, although within $250 \mathrm{~m}$ there was a higher proportion of people classified as the least deprived. Fewer people live in urban areas within $250 \mathrm{~m}$ of a composting facility, compared to those living $>250 \mathrm{~m}$ of a composting facility.

Deprivation patterns, however, vary considerably when stratified by rural and urban areas (Fig. 3). Populations are more deprived in urban areas compared to rural areas in all distance bands, although this is more marked nearer to a composting facility.
The number of incidents and notifications attributed to composting facilities per year are presented in Appendix E.

\section{Discussion}

This is the first study that characterises populations living around intensive farming and composting facilities in England. Over $16 \%$ of the population and more than $15 \%$ of schools are located within 4,828 of an intensive farming facility or $4,000 \mathrm{~m}$ of a composting facility, which contradicts previous opinion that such facilities are mostly located away from housing and schools. The population living within $4,000 \mathrm{~m}$ of a composting facility are mostly located in urban settings, which also contradicts previous opinion that they are mostly located in rural settings. In addition, our study assesses the number of air pollution related incidents and notifications attributed to intensive 

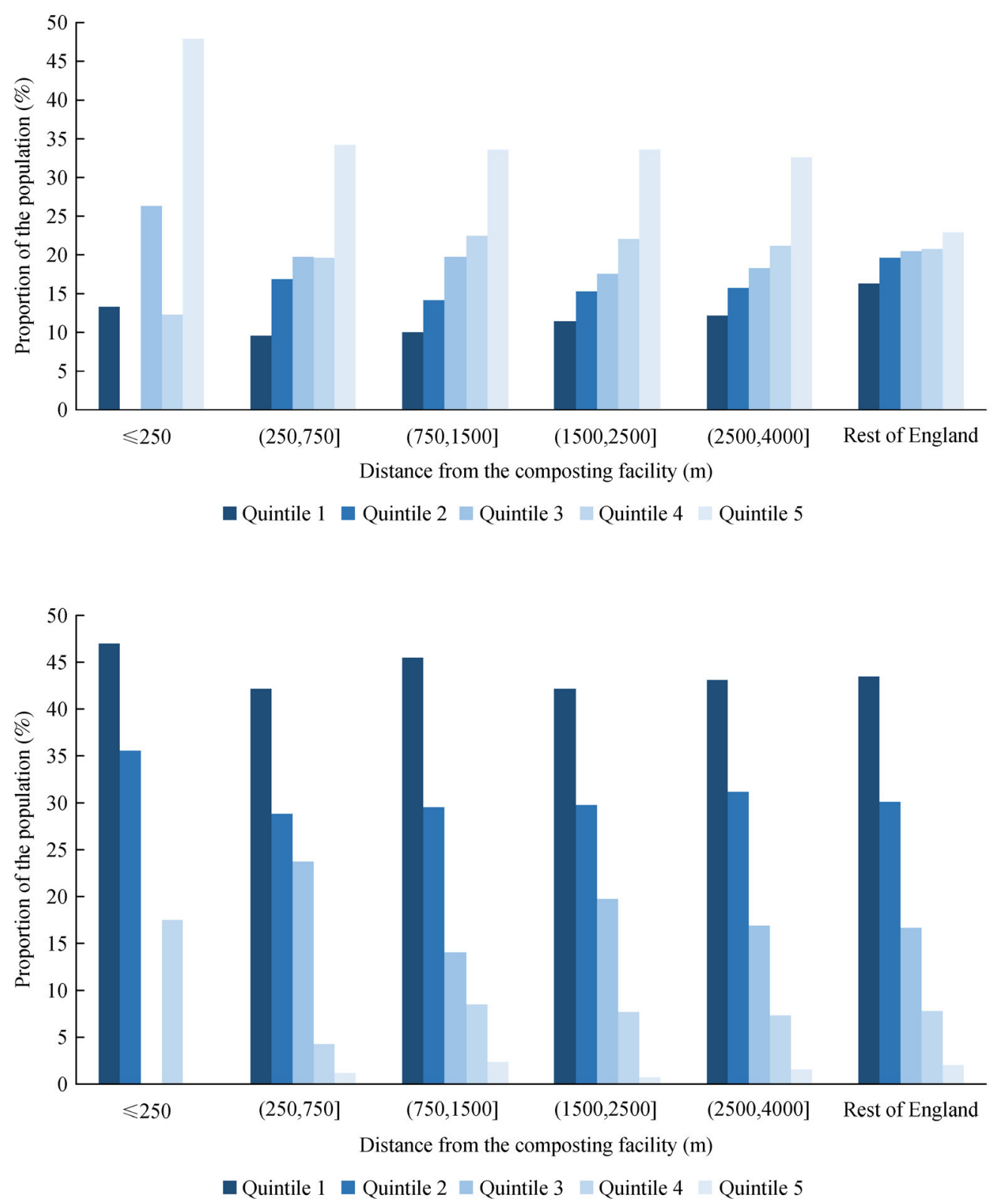

Fig. 3 Proportion of the population living within each Carstairs deprivation quintile by distance band from composting facility for urban areas (top) and rural areas (bottom). A deprivation quintile of 1 represents the least deprived areas

farming and composting facilities over time, to calculate the average number of air pollution related incidents per year per facility and describe the socio-demographic characteristics around facilities with reported incidents.

\subsection{Results interpretation}

Although a large proportion of the population and schools are located within $4,828 \mathrm{~m}$ or $4,000 \mathrm{~m}$ of an intensive farming or composting facility, there are few people and schools within $100 \mathrm{~m}$ or $250 \mathrm{~m}$, respectively. This may be a reflection on how these facilities are regulated; as described in section 2.1, intensive farming and composting facilities over a certain capacity require a permit from the EA. If there are any 'sensitive receptors' (workplaces or dwellings) located within $100 \mathrm{~m}$ of an intensive farming facility or $250 \mathrm{~m}$ of a composting facility, then a sitespecific bioaerosol risk assessment is required (Environment Agency, 2018c). As this is potentially more time consuming and costly to the facility, facilities may therefore purposely cite themselves in areas where these conditions are met.

Areas very close $(100 \mathrm{~m}$ or $250 \mathrm{~m})$ to intensive farming or composting facilities are more rural, with a higher 
proportion of older adults who are less deprived. This may reflect affluent over 65 year olds moving to more rural areas upon retirement.

Areas further away from intensive farming facilities $(100-4,828 \mathrm{~m})$ also inhibit similar population characteristics, however, areas further away from composting facilities $(250-4,000 \mathrm{~m})$ are more urban, deprived, and with fewer older people and more children. Children, deprived populations, and older people are potentially more susceptible to the health risks of bioaerosol exposure. Older adults are more susceptible to respiratory infections as the immune system function declines in old age (The Parliamentary Office of Science and Technology, 2017; Thomas et al., 2019) and therefore are likely to be at greater risk of exposure to pathogenic bioaerosol species and components, as they are emitted in elevated levels from these sources. Children are more prone to environmental risks as they are still developing their lungs and immune systems; increased reported asthma prevalence has been reported in four studies examining children living or attending schools near an intensive farm (Hoopman et al., 2006; Mirabelli et al., 2006; Sigurdarson and Kline, 2006; Pavilonis et al., 2013). However, further work is needed to confirm this.

Deprivation was classified using the Carstairs index, a composite measure of deprivation which focuses of deprivation dimensions associated with urban areas, such as overcrowding and car ownership. The nature of deprivation experienced in rural areas, however, is different to that in urbans areas (Fecht et al., 2017). Rural deprivation is characterised by dimensions such as fuel poverty, hidden unemployment and poor access to services, amenities and health care (Cloke et al., 1997; Defra, 2019). Therefore, the deprivation indices used in this study may not be as relevant for rural populations, such as those living near intensive farming facilities. We applied an adapted Carstairs index for use in rural settings (RCar) to populations living in rural areas near intensive farms in a sensitivity analysis (Appendix C). However, the RCar still contains the variables originally used in the Carstairs index and does not capture the additional dimensions of deprivation associated with in rural areas. In addition, as COA boundaries reflect population distribution with, on average, 300 people, COAs in rural areas cover much larger areas; pockets of deprivation within the larger rural COAs could be masked.

Incidents were often related to a small proportion of intensive farming and composting facilities, suggesting that there are some facilities that have problems with their emissions. The number of incidents and notifications relating to composting facilities are decreasing. This may be due to populations becoming more ecologically and environmentally aware, and therefore becoming more accepting of composting facilities (as a sustainable way of recycling organic material), and less accepting of intensive farms (which may lead to increased environmental pollution). Overall, however, there are fewer incidents attributed to intensive farming facilities compared to composting facilities. There are also fewer composting facilities than intensive farms, meaning that on average there are more incidents per composting facility.

\subsection{Evidence from epidemiological studies}

It was beyond the scope of this study to conduct analyses of health records/outcomes in relation to proximity to intensive farming and composting facilities. However, a recent systematic review summarised results from 16 studies that used proxy measures for exposure to examine community health effects surrounding intensive farming facilities (Douglas et al., 2018). The findings from these heterogenous studies were mixed, with some reporting adverse associations with respiratory health, while others report protective associations. Four studies concerned children (Hoopman et al., 2006; Mirabelli et al., 2006; Siguardson and Kline 2006; Pavilonis et al., 2013), which reported relatively consistent evidence of increased selfreported asthma incidence in children living, or attending schools, near intensive farming facilities. In addition, Douglas et al., (2016) used distance from composting facility as a proxy for exposure to examine the health effects of communities living near composting facilities. This was followed up by a more recent study which used modelled Aspergillus fumigatus to estimate bioaerosol exposure (Roca Barcelo et al., 2020). Neither of these studies provided evidence for an increased risk of respiratory-related hospital admissions (although hospital admissions represent severe respiratory episodes). Older community health studies were summarised in a systematic review conducted by Pearson et al., (2015).

\subsection{Strengths and limitations}

We were able to include all intensive farming and composting facilities with a permit to operate at the end of 2017 in England in our study, and incident and notification data attributed to these facilities using databases collected by the EA for permitting and regulatory purposes. These data were not collected for the purpose used in this study, and therefore provided some limitations when adapting the data. We geocoded the locations of the sites using the national grid reference provided in the data. This would have introduced some errors, as the national grid reference may not reflect the location of bioaerosol emissions from these facilities. However, the national grid references are checked by the EA, and will represent the location of the site, typically depicting the site entrance (EA, Environment and Business Department, personal communication, 15th June 2018). We used incident and notification data to calculate the 
average number of air pollution related incidents per year per facility and describe the socio-demographic characteristics around facilities with reported incidents. This data captured all incidents relating to 'Atmospheric Pollutant and Effects', which is not limited solely to bioaerosols, and may also include odour. Therefore, many of the notifications recorded may not be attributable to bioaerosol exposure.

We also did not account for that fact that the radii around these facilities may overlap, and-some of the population may live within close proximity to more than one intensive farming and/or composting facility, and therefore be more exposed to anthropogenic bioaerosol concentrations.

We summarised population characteristics within defined distance bands around the intensive farming and composting facilities, as described in Table 1. These distances were justified, where possible, based on results from studies that measured bioaerosol concentrations in communities surrounding these facilities. However, other distance bands were added based on values used in epidemiological studies that used proxy measured for exposure. Unfortunately, there are a limited number of studies that have measured bioaerosols from intensive farming and composting facilities in the surrounding community, and in the few studies that have, this has been typically limited to sampling within $1-1.5 \mathrm{~km}$ (see Table 1).Therefore, we are currently unable to say with certainty that bioaerosols will disperse as far as $4,828 \mathrm{~m}$ from intensive farming facilities or $4,000 \mathrm{~m}$ from composting facilities, the full extent of the distance bands examined in this study. However, bioaerosols emitted from these facilities may, theoretically, stay suspended over longer distances due to their small size and travel over large geographical distances (Tamer Vestlund et al., 2014; Fröhlich-Nowoisky et al., 2016; Feeney et al., 2018). This theory is also supported by a recent dispersion modelling study, where Aspergillus fumigatus concentrations were estimated within $4 \mathrm{~km}$ of composting facilities in England (Williams et al., 2019); although modelled concentrations typically plateaued at approximately $1.5-2 \mathrm{~km}$, there were some postcodes within the highest quintile of modelled concentrations beyond $2 \mathrm{~km}$.

It was only possible to include farms classed as intensive under the IED, as these are regulated by the EA. It was not possible to include other types of farms (e.g. smaller poultry and pig farms, cattle and sheep farms), although these may still represent an important anthropogenic source of bioaerosols. There are other anthropogenic sources of bioaerosol, including sewage treatment works and wastewater treatment plants, which were not explored in this study. Bioaerosol emissions and dispersion from such sources are not well explored, and site-specific bioaerosol risk assessment are not required from the EA for these facilities.
We summarised population characteristics based on area level data, not individual level data. Socio-demographic characteristics are not available on a national scale at individual level, and therefore we use area level data available at COA level instead, which is the highest resolution that detailed population data are available. When summarising population characteristics data with distance from anthropogenic sources, we would have introduced unavoidable errors, as some COAs, particularly those located in rural area, cover large areas, and therefore the actual distance between individual residents to an anthropogenic bioaerosol source will vary considerably within the COA. To mitigate this source of potential misclassification, we used population-weighted centroids to assign distance from each anthropogenic bioaerosol source to the population within the COA, rather than geometric centroids, to reflect the population within each COA.

We were able to use the most recent data available at the time of analysis; intensive farming and composting facility permit information were available for 2017; school information from July 2017; and population data were available from the last UK census in 2011, However, this information might have slightly changed since data was last collected.

\subsection{Future work and impact}

Previous systematic reviews have highlighted the need for more community health studies to be conducted in regards to bioaerosols exposure from intensive farming and composting facilities (Pearson et al., 2015; Douglas et al., 2018; Robertson et al., 2019). This study has highlighted that a large proportion of the population in England live near these pollutant sources and reinforces these recommendations. Future studies should consider assessing the health risks of vulnerable populations, including children living near composting facilities, particularly those in more deprived areas.

The data used in the study can be utilised to identify intensive farming and composting facilities with large, or more vulnerable, populations living around them, which can inform risk management strategies, targeted at specific sites. This data can also inform future bioaerosol sampling campaigns, exposure assessment and health studies, so that sites with large, vulnerable or deprived populations or a large number of schools in proximity to the sites, or sites with a lot of notifications or incidents can be targeted.

\section{Conclusions}

We have described the characteristics of populations living near intensive farming and composting facilities, and calculated the average number of air pollution related 
incidents per year per facility and described the sociodemographic characteristics around these facilities. Results show that around a sixth of the population (16.9\%) live within $4,000 \mathrm{~m}$ of a composting facility and a fifth of the population $(18.0 \%)$ live within $4,828 \mathrm{~m}$ ( 3 miles) of an intensive farm in England. However, few people live very close to composting facilities $(0.01 \%$ live within $250 \mathrm{~m})$ or intensive farms $(<0.01 \%$ live within $100 \mathrm{~m})$, although these people tend to be older compared to the rest of the population. In addition, people near composting facilities live in more urban areas, which are more deprived. The number of incidents relating to atmospheric pollutant and effects attributed to composting facilities are decreasing (61.40\% decrease in incidents reported in 2011 vs 2017), but increasing for intensive farms $(92.31 \%$ increase in incidents reported in 2011 vs. 2017), but are limited to a small proportion of sites. Results indicate that populations living in the vicinity of composting facilities are mostly located in urban areas. This supports the need for more community health studies to be conducted, particularly in populations potentially more susceptible to the health effects of bioaerosol exposure, including older adults and children. Results could also be used to inform risk management strategies at high incident sites, and future monitoring campaigns.

Acknowledgements Philippa Douglas was funded by the MRC-PHE Centre for Environment and Health via an early career research fellowship. The research was part funded by the National Institute for Health Research Health Protection Research Unit (NIHR HPRU) in Health Impact of Environmental Hazards at King's College London in partnership with Public Health England (PHE) and Imperial College London. The work of the UK Small Area Health Statistics Unit is funded by Public Health England as part of the MRC-PHE Centre for Environment and Health, funded also by the UK Medical Research Council. The views expressed are of the authors and not necessarily those of the MRC, the NHS, the NIHR, the Department of Health \& Social Care or Public Health England. We thank the Environment Agency (EA) for providing the composting and intensive farming facility permit and CICs data, and for aiding with its interpretation; these data were provided to us via email under the Environment Agency Conditional Licence (at the website www.gov.uk/government/publications/environment-agency-conditional-licence/environment-agency-conditional-licence). The population data were supplied by the Office for National Statistics (ONS), derived from small area population estimates, data available under the UK Open Government License v.3.0 (Contains National Statistics data (C) Crown copyright and database right 2020. Contains OS data (C) Crown copyright (2020)). Schools data were obtained from the .GOV website (freely available online at website www.gov.uk/government/publications/schools-in-england\#history). Data were provided to be used solely for academic, personal and/or non-commercial purposes.

Electronic Supplementary Material Appendix is available in the online version of this article at https://doi.org/10.1007/s11783-020-1332-z and is accessible for authorized users.

Open Access This article is licensed under a Creative Commons Attribution 4.0 International License, which permits use, sharing, adaptation, distribution and reproduction in any medium or format, as long as you give appropriate credit to the original author(s) and the source, provide a link to the Creative Commons licence, and indicate if changes were made. The images or other third party material in this article are included in the article's Creative Commons licence, unless indicated otherwise in a credit line to the material.
If material is not included in the article's Creative Commons licence and your intended use is not permitted by statutory regulation or exceeds the permitted use, you will need to obtain permission directly from the copyright holder. To view a copy of this licence, visit http://creativecommons.org/licenses/by/4.0/.

\section{References}

Allergy U K (2020). Allergy prevalence: Useful facts and figures. Available online at the website www.allergyuk.org/assets/000/001/ 369/Stats_for_Website_original.pdf?1505209830 (accessed March $31,2020)$

Asthma U K (2020). Asthma facts and statistics. Available online at the website www.asthma.org.uk/about/media/facts-and-statistics/ (accessed March 31, 2020)

Brooks J P, Gerba CBioaerosol contamination of produce: Potential issues from an unexplored contaminent route (2014). In: Matthews K R, Sapers G M, Gerba, C P, eds. The Produce Contamination Problem. Causes and solutions. 2nd ed. New York: Academic Press

Carstairs V, Morris R (1989). Deprivation: Explaining differences in mortality between Scotland and England and Wales. British Medical Journal, 299(6704): 886-889

Chief Medical Officer (2018). Annual Report of the Chief Medical Officer 2017. Available online at the website www.gov.uk/government/publications/chief-medical-officer-annual-report-2017-healthimpacts-of-all-pollution-what-do-we-know (accessed March 31, 2020).

Cloke P, Milbourne P, Thomas C (1997). Living lives in different ways? Deprivation, marginalization and changing lifestyles in rural England. Transactions of the Institute of British Geographers, 22: 210-230

Defra (2019). Department of Environment, Food, and Rural Affairs. Fuel Poverty Statistics. Available online at the website www.gov.uk/ government/statistics/fuel-energy-and-fuel-poverty-in-rural-areas (accessed March 31, 2020)

Douglas P, Bakolis I, Fecht D, Pearson C, Leal Sanzhez M, Kinnersley R, De Hoogh K, Hansell A L (2016). Respiratory hospital admission risk near large composting facilities. International Journal of Hygiene and Environmental Health, 219(4-5): 372-379

Douglas P, Robertson S, Gay R, Hansell A L, Gant T W (2018). A systematic review of the public health risks of bioaerosols from intensive farming. International Journal of Hygiene and Environmental Health, 221(2): 134-173

Douwes J, Thorne P, Pearce N, Heederik D (2003). Bioaerosol health effects and exposure assessment: progress and prospects. Annals of Occupational Hygiene, 47(3): 187-200

Environment Agency (2014). Waste Exemption: T23 Aerobic Composting and Associated Prior Treatment. Available online at the website www.gov.uk/guidance/waste-exemption-t23-aerobic-compostingand-associated-prior-treatment (accessed March 31, 2020)

Environment Agency Publication Environment Agency (2018a). England: Effective permits for an Installation Activity as at end December 2017. Environment Agency Publication

Environment Agency (2018b). Permitted composting activities and noneffective composting sites in England- End December 2017. Environment Agency Publication 
Environment Agency (2018c). Guidance. Bioaerosol monitoring at regulated facilities - use of M9: RPS 209. Available online at the website www.gov.uk/government/publications/bioaerosol-monitoring-at-regulated-facilities-use-of-m9-rps-209/bioaerosol-monitoringat-regulated-facilities-use-of-m9-rps-209 (accessed September 7, 2020)

Fecht D, Jones A, Hill T, Lindfield T, Thomson R, Hansell A L, Shukla $R$ (2017). Inequalities in rural communities: adapting national deprivation indices for rural settings. Journal of Public Health, 40 (2): 419-425

Feeney P, Rodriguez S F, Molina R, Mcgillicuddy E, Hellebust S, Quirke M, Daly S, O'connor D, Sodeau J (2018). A comparison of on-line and off-line bioaerosol measurements at a biowaste site. Waste Management (New York, N.Y.), 76: 323-338

Fröhlich-Nowoisky J, Kampf C J, Weber B, Huffman J A, Pöhlker C, Andreae M O, Lang-Yona N, Burrows S M, Gunthe S S, Elbert W, Su H, Hoor P, Thines E, Hoffmann T, Després V R, Pöschl U (2016). Bioaerosols in the Earth system: Climate, health, and ecosystem interactions. Atmospheric Research, 182: 346-376

GOV.UK (2017). Schools in England. Available online at the website www.gov.uk/government/publications/schools-in-england\#history (accessed March 31, 2020)

Gov.Uk (2018). Intensive farming risk assessment for your environmental permit. Available online at the website www.gov.uk/guidance/ intensive-farming-risk-assessment-for-your-environmental-permit (accessed April 21, 2020)

Hoopman M, Hehl O, Niesel F, Werfel T (2006). Associations between Bioaerosols coming from Livestock facilities and Asthmatic Symptoms in Children. Gesundheitswesen (Bundesverband der Ärzte des Öffentlichen Gesundheitsdienstes (Germany)), 68(8/9): 575-584

Huijskens E G W, Smit L a M, Rossen J W A, Heederik D, Koopmans M (2016). Evaluation of Patients with Community-Acquired Pneumonia Caused by Zoonotic Pathogens in an Area with a High Density of Animal Farms. Zoonoses and Public Health, 63: 160-166

Lacey J, Dutkiewicz J (1994). Bioaerosols and occupational lung disease. Journal of Aerosol Science, 25(8): 1371-1404

Mirabelli M C, Wing S, Marshall S W, Wilcosky T C (2006). Asthma symptoms among adolescents who attend public schools that are located near confined swine feeding operations. Pediatrics, 118(1): $66-75$

ONS (2020a). Office for National Statistics. National population projections: 2018-based. Available online at the website www.ons. gov.uk/peoplepopulationandcommunity/populationandmigration/ populationprojections/bulletins/nationalpopulationprojections/ 2018based (accessed March 31, 2020)

ONS (2020b). Office for National Statistics. Census geography. Available online at the website www.ons.gov.uk/methodology/ geography/ukgeographies/censusgeography\#output-area-oa (accessed March 31, 2020)

ONS (2020c). Office for National Statistics. 2011 rural/urban classification. Available online at the website www.ons.gov.uk/methodology/ geography/geographicalproducts/ruralurbanclassifications/2011ruralurbanclassification (accessed March 31, 2020)

Pankhurst L J, Deacon L J, Liu J, Drew G H, Hayes E T, Jackson S, Longhurst P J, Longhurst J W S, Pollard S J T, Tyrrel S F (2011).
Spatial variations in airborne microorganism and endotoxin concentratinos at green waste composting facilities. International Journal of Hygiene and Environmental Health, 214(5): 376-383

Pavilonis B T, Sanderson W T, Merchant J A (2013). Relative exposure to swine animal feeding operations and childhood asthma prevalence in an agricultural cohort. Environmental Research, 122: 74-80

Pawankar R S, Sánchez-Borges M, Bonini S, Kaliner M AThe burden of allergic diseases. (2013). In: Pawankar R, Canonica G W, Holgate S T, Lockey R F, Blaiss M S, eds. World Allergy Organization (WAO) white book on allergy: Update 2013. World Allergy Organization

Pearson C, Littlewood E, Douglas P, Robertson S, Gant T W, Hansell A L (2015). Exposures and health outcomes in relation to bioaerosol emissions from composting facilities: A systematic review of occupational and community studies. Journal of Toxicology and Environmental Health Part B, 18(1): 43-69

Pepper I L, Dowd S EAeromicrobiology (2009). In: Maier R M, Pepper I L, Gerba C P, eds. Envionmental Microbiology. 2nd ed. New York: Academic Press

Radon K, Schulze A, Ehrenstein V, Van Strien R T, Praml G, Nowak D (2007). Environmental Exposure to Confined Animal Feeding Operations and Respiratory Health of Neighboring Residents. Epidemiology, 18(3): 300-308

Reinthaler F, Marth E, Eibel U, Enayat U, Feenstra O, Friedl H, Köck M, Pichler-Semmelrock F P, Pridnig G, Schlacher R (1997). The assessment of airborne microorganisms in large-scale composting facilities and their immediate surroundings. Aerobiologia, 13(3): $167-175$

Robertson S, Douglas P, Jarvis D, Marczylo E (2019). Bioaerosol exposure from composting facilities and health outcomes in workers and in the community: A systematic review update. International Journal of Hygiene and Environmental Health, 222(3): 364-386

Roca-Barcelo A, Douglas P, Fecht D, Sterrantino A F, Williams B, Blangiardo M, Gulliver J, Hayes E T, Hansell A L (2020). Risk of respiratory hospital admission associated with modelled concentrations of Aspergillus fumigatus from composting facilities in England. Environmental Research, 183: 108949

Schinasi L, Horton R A, Guidry V T, Wing S, Marshall S W, Morland K $B$ (2011). Air pollution, lung function, and physical symptoms in communities near concentrated swine feeding operations. Epidemiology, 22: 208-215

Smit L M, Hooiveld M, Van Der Sman-De Beer F, Opstal-Van Winden A W J, Beekhuizen J, Wouters I M, Yzermans C J, Heederik D (2014). Air pollution from livestock farms, and asthma, allergic rhinitis and COPD among neighbouring residents. Occupational Environmental Medicine, 71: 134-140

Sigurdarson S, Kline J (2006). School proximity to concentrated animal feeding operations and prevalence of Asthma in Students. Chest, 129 (6): 1486-1491

Swan J R M, Kelsey A, Crook B, Gilbert E J (2003). Occupational and Environmental Exposure to Bioaerosols from Composts and Potential Health Effects: A Critical Review of Published Data. London: Health and Safety Executive Publication

Sykes P, Jones K, Wildsmith J D (2007). Managing the potential public health risks from bioaerosol liberation at commercial composting sites in the UK: An analysis of the evidence base. Resources, Conservation and Recycling, 52(2): 410-424 
Tamer Vestlund A, Al-Ashaab R, Tyrrel S F, Longhurst P J, Pollard S J T, Drew G H (2014). Morphological classification of bioaerosols from composting using scanning electron microscopy. Waste management, 34(7): 1101-1108

The European Parliament and the Council of the European Union (2010). Directive 2010/75/EU of the European Parliament and of the Council of 24 November 2010 on industrial emissions (integrated pollution prevention and control). Available online at the website eurlex.europa.eu/legal-content/EN/TXT/PDF/?uri = CELEX:32010L0075\&from $=$ EN (accessed March 31, 2020)

The Parliamentary Office of Science and Technology (2017). UK trends in infectiuos disease. Available online at the website post.parliament. uk/research-briefings/post-pn-0545/ (accessed March 31, 2020)

Thomas E T, Guppy M, Straus S E, Bell K J L, Glasziou P (2019). Rate of normal lung function decline in ageing adults: A systematic review of prosective cohort studies. BMJ Open, 9(6): e028150

Walser S M, Gerstner D G, Brenner B, Bunger J, Eikmann T, Janssen B, Kolb S, Kolk A, Nowak D, Raulf M, Sagunski H, Sedlmaier N,
Suchenwirth R, Wiesmuller G, Wollin K M, Tesseraux I, Herr C E (2015). Evaluation of exposure-response relationships for health effects of microbial bioaerosols: A systematic review. International Journal of Hygiene and Environmental Health, 218(7): 577-589

Wery N (2014). Bioaerosols from composting facilities: A review. Frontiers in Cellular and Infection Microbiology, 4(42); 1-9

Williams B, Douglas P, Roca Barcelo A, Hansell A L, Hayes E (2019). Estimating Aspergillus fumigatus exposure from outdoor composting activities in England between 2005 and 2014. Waste Management (New York, N.Y.), 84: 235-244

Williams M, Lamarre B, Butterfield D, Tyrrel S, Longhurst P, Drew G H, Al-Ashaab R, Nelson A, Gladding T, Simpson A, Coughlin D, Hansell A (2013). Department for Environment Food and Rural Affairs Report WR1121 - Monitoring bioaerosol and odour emissions rom composting facilities. Available online at the website randd.defra.gov.uk/Default.aspx $?$ Menu $=$ Menu\&Module $=$ More $\&-$ Location $=$ None $\&$ Completed $=0 \&$ ProjectID $=17214$ (accessed July $17,2020)$ 